\begin{tabular}{|l|l|l||}
\hline \multicolumn{2}{|c|}{ PublisherInfo } \\
\hline \hline PublisherName & $:$ & BioMed Central \\
\hline \hline PublisherLocation & $:$ & London \\
\hline \hline PublisherImprintName & $:$ & BioMed Central \\
\hline \hline
\end{tabular}

\title{
Does head elevation decreases cerebral blood flow?
}

\begin{tabular}{|l|l|l||}
\hline \multicolumn{2}{|c||}{ ArticleInfo } \\
\hline \hline ArticleID & $:$ & 4198 \\
\hline \hline ArticleDOI & $:$ & $10.1186 /$ ccf-2000-5200 \\
\hline \hline ArticleCitationID & $:$ & 5200 \\
\hline \hline ArticleSequenceNumber & $:$ & 57 \\
\hline \hline ArticleCategory & $:$ & Paper Report \\
\hline \hline ArticleFirstPage & $:$ & 1 \\
\hline \hline ArticleLastPage & $:$ & 3 \\
\hline \hline & & RegistrationDate : 2000-5-31 \\
\hline ArticleHistory & $:$ & OnlineDate \\
\hline \hline ArticleCopyright & $:$ & Current Science Ltd2000-5-31 \\
\hline \hline ArticleGrants & $:$ & \\
\hline \hline ArticleContext & $:$ & 1305422 \\
\hline \hline
\end{tabular}




\section{Keywords}

Cerebral blood flow, cerebral perfusion pressure, head position, intracranial pressure, jugular bulb pressure

\section{Comments}

An interesting observational study that looks at changes in cerebrovascular hemodynamics with changes in head elevation. It is usual to nurse patients with raised intra cranial pressure (ICP) with head elevation up to $30^{\circ}$, to facilitate venous drainage and treat the elevated ICP. However, the results of this study show, this may be accompanied by significant and linear drop in cerebral blood flow (CBF) during head elevation from $0^{\circ}$ to $45^{\circ}$ and this may potentially worsen the secondary injury. In addition, there was an increase in ICP with head elevation beyond $30^{\circ}$. The technique of CBF measurement by thermodilution is interesting in its own right and further details can be found in the additional comments below.

\section{Introduction}

Head elevation as a treatment to lower ICP in patients with intracranial hypertension has been challenged, as with head elevation both ICP and cerebral perfusion pressure (CPP) have been shown to fall. Changes in $\mathrm{CBF}$ however have not been quantified. Hence the rationale of this study to clarify the changes in cerebrovascular hemodynamics with head elevation.

\section{Methods}

- Prospective, observational study in 37 adult patients with coma due to severe intracranial lesions. 
- The effect of $0^{\circ}, 15^{\circ}, 30^{\circ}$ and $45^{\circ}$ head elevation on CBF, CPP, ICP and arteriovenous pressure gradient were studied. The angles were measured using a goniometer

- All patients were mechanically ventilated, sedated and paralyzed. The mean Glasgow coma scale was 6 (range 3-11).

- $\mathrm{CBF}$ was measured using the thermodilution method.

- ICP was measured by catheter inserted into the frontal horn of the lateral ventricle

- Jugular catheters were inserted ipsilaterally into the vein on the side of the unilateral hemispheric lesion or on the right side in case of bihemispheric lesions.

\section{Results}

With head elevation from $0^{\circ}$ to $45^{\circ}, \mathrm{CBF}$ decreased from $46.3 \pm 4.8$ to $28.7 \pm 2.3 \mathrm{~mL} / \mathrm{min} / 100 \mathrm{~g}(P<$ 0.01); CPP remained stable up to $30^{\circ}$ and decreased from $62 \pm 3$ to $57 \pm 4 \mathrm{mmHg}$ between $30^{\circ}$ and $45^{\circ}$ $(P<0.05)$ and ICP decreased from $25 \pm 2$ to $14 \pm 1 \mathrm{mmHg}$ between $0^{\circ}$ to $30^{\circ}(P<0.01)$ and increased from $14 \pm 1$ to $16 \pm 2(P<0.05)$ between $30^{\circ}$ and $45^{\circ}$. On multiple logistic regression analysis using a mathematical model, and even correcting for a calculated CPP, the CBF decreased by $0.15 \mathrm{~mL} / \mathrm{min} /$ $100 \mathrm{~g} / 10$ head end elevation suggesting despite anything there was truly an independent decrease in blood flow.

\section{Additional information}

Melot C et al: Estimation of cerebral bloodflow at the bedside by continuos jugular thermodilution. $J$ Cereb Blood Flow Metab 1996, 16:1263-1270

\section{References}

1. Moraine J-J, Berre $\mathrm{J}$ and Melot C: Is cerebral perfusion pressure a major determinant of cerebral blood flow during head elevation in comatose patients with severe intracranial lesions?. J Neurosurg. 2000, 92: 606-614.

This PDF file was created after publication. 